\title{
The Serological Identity of a Yellow-Pigmented Streptococcus
}

\author{
By C. L. HANNAY \\ National Institute for Research in Dairying, University of Reading
}

SUMMARY: A yellow-pigmented Streptococcus was isolated from certain dairy cows. The three strains examined were closely related to Strep. faecalis but differed from it in fermenting raffinose. The organism produced a tyrosine decarboxylase. Serologically the organism belonged to Lancefield group D, Sharpe type 10.

The literature contains many references to streptococci which produce pigment under anaerobic, or semi-anaerobic conditions, for example, in deep agar or broth cultures (Durand \& Giraud, 1923; Lancefield, 1934; Plummer, 1941). The Streptococcus reported here produced pigment on the surface of aerobic plates.

It was isolated three times from the teats of one cow which was being used in an experiment at the Institute by my colleague, $\mathbf{M r} \mathbf{F}$. K. Neave, on the prevention of the spread of Strep. agalactiae by means of nisin. It was not isolated from any of sixty other cows in the Institute herd. It was also isolated twice from the hands of the milker concerned. When first noticed it was in almost pure culture on the plate and may have been overlooked earlier. A year later a similar organism was isolated from another herd in which no antibiotics had been used.

Three strains, two isolated from the Institute's herd and one from the other herd, have been identified biochemically and serologically as belonging to group D.

\section{SEROLOGICAL METHODS}

Preparation of antiserum. Group D sera were produced from the pigmented Streptococcus no. 1, Strep. bovis 'Rosalie 20', Strep. faecalis and from Strep. durans (no. 98D). The organisms were grown for $48 \mathrm{hr}$. at $37^{\circ}$ in $1 \%$ glucose Lemco broth, and the suspension prepared in a magnetic shaker according to the method of Shattock (1949). Potent group sera were produced by giving each rabbit, over a period of 3 weeks, six intravenous injections of $1 \mathrm{ml}$. of freshly prepared suspension.

Precipitin test. Hydrochloric acid extracts (Lancefield, 1933) were layered over serum contained in glass tubes of $3 \mathrm{~mm}$. internal diameter. The juncture of the two fluids was examined after $5 \mathrm{~min}$. for the presence of a precipitate.

Absorption. The complete absorption of group antibodies from potent group D serum appears to require a heavier suspension of organisms than do sera against some of the other Lancefield groups. The technique of Shattock (1949) was therefore used. 


\section{RESULTS}

General characteristics. On first isolation on blood plates the colonies were strongly pigmented, varying in colour from yellow to dirty brown. On subsequent plating the colonies became very pale but when the growth was aggregated with a platinum loop the bacterial mass was a primrose colour. Stab cultures in nutrient agar were incubated for $24 \mathrm{hr}$., and when placed in the refrigerator formed a dark yellow brown growth around the site of inoculation. The packed bacterial mass obtained by centrifuging the growth from $24 \mathrm{hr}$. cultures grown in broth containing $0.2 \%$ dextrose was yellow, and when the supernatant was decanted and the bacterial mass left exposed to the air the pigment was slowly oxidized to a brownish colour.

Biochemical characteristics. The biochemical characteristics of all three strains were identical and conformed to those of Strep. faecalis, except that they fermented raffinose. They produced tyrosine decarboxylase (Sharpe, 1948), grew at pH 9.6 (Shattock \& Hirsch, 1947), and hydrolysed arginine (Niven, Smiley \& Sherman, 1942).

\section{Serology}

Serological grouping. This organism presented no difficulties in the production either of a strong extract or of a potent group serum. Extracts reacted with the group D sera produced from Strep. bovis, Strep. durans and Strep. faecalis, but not with the other sera in Lancefield groups A-N. The serum produced from strain no. 1 reacted with extracts prepared from fourteen known group D strains including a number of extracts of Strep. bovis, but not with extracts from strains of Lancefield groups $\mathbf{A}-\mathbf{N}$ or with an extract containing staphylococcal nucleoprotein. Tables 1 and 2 show that strain no. 1 absorbed all group antibodies from the Strep. durans and Strep. bovis sera and vice versa with serum prepared from strain no. 1.

\section{Table 1. Absorption of group $D$ antibodies by the pigmented Streptococcus no. 1}

\begin{tabular}{|c|c|c|c|}
\hline & Gro & serum & \\
\hline & Serum ' 98 D' & Serun & lie $20^{\circ}$ \\
\hline ixtract & Unabsorbed Absor & Unabso & osorbed \\
\hline & + & + & - \\
\hline ie $20^{\prime}$ & + & + & - \\
\hline nd $G$ & + & + & - \\
\hline ococci' (nos. 1-3) & + & + & - \\
\hline
\end{tabular}

Serological typing. The three strains of pigmented bacteria were typed by the slide agglutination and precipitin ring tests, using specific absorbed serum. Each of the three strains reacted specifically with type 10 antiserum (Sharpe, 1949), and gave no cross-reactions with the other twenty type sera available in this laboratory at that time. 


\section{DISCUSSION}

But for the fermentation of raffinose these chromogenic strains are closely related to Strep. faecalis. In this laboratory group $\mathbf{D}$ organisms differing from the accepted definition of Strep. faecalis are usually regarded as variants, but in the light of the recent work of Sharpe (1949) it seems doubtful whether any

Table 2. Absorption of group serum from the pigmented Streptococcus by group D streptococci

$\begin{array}{lccc}\text { Unabsorbed } & \overbrace{\text { O8 D }}^{\text {Serum 'Pigmented Streptococcus' no. 1 }} \\ \text { Extract } & + & - & - \\ \text { Absorbed by }\end{array}$

raffinose fermenters should be included in the species Strep. faecalis. Sharpe tested a large number of strains of group D streptococci isolated from infants' faeces for their tyrosine decarboxylase activity and found that all those organisms which were typical members of Strep. faecalis or the varieties zymogenes and liquefaciens, as well as Strep. durans, possessed a high decarboxylase activity, whereas all of those organisms fermenting raffinose, for example Strep. bovis and organisms biochemically similar to our chromogenic strains, had little or no tyrosine decarboxylase activity.

The serological type 10 of Sharpe (1949) is rare and has only been identified twice. Neither strain produced pigment or decarboxylated tyrosine. It would appear reasonable to classify the chromogenic strains which fermented raffinose and produced a tyrosine decarboxylase as Lancefield group D, Sharpe type 10, without attempting to give them a specific name.

I should like to express my thanks to Dr A. T. R. Mattick for his interest in these organisms, to Mr F. K. Neave for the cultures, and to Miss M. E. Sharpe for typing the cultures and for permission to refer to unpublished work.

\section{REFERENCES}

Durand, P. \& Giraud, P. (1923). Les streptococoques chromogènes. C.R. Acad. Sci., Paris, 177, 1333.

LANCEFIELD R. C. (1933). A serological differentiation of human and other groups of haemolytic streptococci. J. exp. Med. 57, 571.

LANCEFIELD, R. C. (1934). Loss of properties of haemolysin and pigment formation without change in immunological specificity in a strain of Streptococcus haemolyticus. J. exp. Med. 59, 459.

Niven, C. F., Smmey, K. L. \& Sherman, J. M. (1942). The hydrolysis of arginine by streptococci. J. Bact. 43, 651 .

Plummer, H. (194,1). A serological and biochemical study of haemolytic streptococi. J. Immunol. 42, 91. 
Sharpe, M. E. (1948). Some biochemical characteristics of group D streptococci isolated from infants' faeces, with special reference to their tyrosine decarboxylase activity. Proc. Soc. Appl. Bact. p. 13.

Sharpe, M. E. (1949). Personal communication.

ShatTock, P. M. F. (1949). The streptococci of group D; the serological grouping of Streptococcus bovis and observations on serologically refractory Group D strains. J. gen. Microbiol. 3, 80.

Shattock, P. M. F. \& Hirsch, A. (1947). A liquid medium buffered at pH $9 \cdot 6$ for the differentiation of Streptococcus faecalis from Streptococcus lactis. J. Path. Bact. 59, 495.

(Received 19 October 1949) 